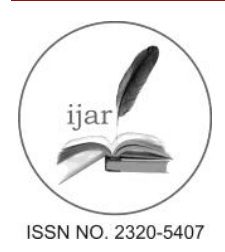

\section{Journal homepage:http://www.journalijar.com} Journal DOI: 10.21474/IJAR01

\section{RESEARCH ARTICLE}

INTERNATIONAL JOURNAL

OF ADVANCED RESEARCH

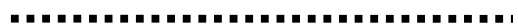

Improving Kochiaindica plants utilization for feeding small ruminants under saline conditions of Sinai, Egypt.

El Shereef* AA, Helal HG, Eid EY, Abo Bakr S, El Shaer HM and Fahmy AA. Animal and Poultry Nutrition Department, Desert Research Center, Matariya, Cairo, Egypt.

\section{Manuscript Info}

Manuscript History:

Received: 12 May 2016

Final Accepted: 16 June 2016

Published Online: July 2016

Key words:

Kochia plant, feed additives, nutritive values, milk yield, milk composition, blood calcium levels, ewes

*Corresponding Author

El Shereef* AA.

\begin{abstract}
Kochiaindica plant provides an important part of forage requirements for sheep and goat, particularly under saline conditions of Sinai, Egypt. However, this plant contained higher levels of some secondary metabolites which had negative effects on animal performance. Therefore, the present study aimed to improve the utilization of Kochiaindica plant by different feed additives to alleviate their adverse effect on animal's nutrition and subsequently their production.

A digestibility trial was conducted using 12 adult rams which were divided into 3 groups ( 4 animals in each),then they were randomly distributed to fed three experimental silagesthe first group fedKochia silage (S1) without any feed additives as control ration, the second group fed Kochia silage mixed with $1 \%$ ammonium chloride (S2). The third group fedKochia silage mixed with $5 \%$ bentonite $(\mathrm{S} 3)$.

By the end of the digestibility trial, a feeding trial was conducted using39 pregnant Barki ewes. The ewes were selected and randomly distributed into three groups (13 in each).The same experimental rations of the digestibility trial were offered ad libduring the feeding trial.

Data showed that, digestibility coefficients of all feed nutrientsand nutritive values for S3were ( $\mathrm{p}<0.05)$ improved compared toS1.Daily gain of lambs in group 3 exceeded by $10 \%$ than their mates in group1 (S1). Liver and kidney function were slightly improved for ewes fed S2 and S3 compared to those fed S1. Blood calcium bioavailability was significantly increased for ewes fed ration contained bentonite(S3).

It could be concluded that Kochia silage could provide available feed materials and solve the feed shortage under marginal conditions. Either ammonium chloride or bentonite addition to Kochia silagehad desirable effects on nutrients digestion, blood calcium bioavailability, kidney and liver function and consequently on Barki ewes' performance and their offspring.
\end{abstract}

Copy Right, IJAR, 2016,. All rights reserved.

\title{
Introduction:-
}

Kochia (indica or scoparia) are annual plants which belong to the family Chenopodiaceae. These plants are adapted to be grown under drought and /or salt affected lands (EI Shaer, 2010). It gives great biomass (approximately averaged 7 ton green fodder / ha. in addition to reasonable nutritive values(in terms of digested energy and protein)which are comparable to that of cloverand alfalfa hays cultivated in Research South Sinai ResearchStation (El Shereef, 2016). Several studies indicated that Kochiaindica contained higher concentrations of some secondary metabolites such as oxalate, saponnins, alkaloids, and tannins which had negative effects on animal performance (Undersanderet al., 1990). Previous investigators reported that drying or ensiling Kochia reduced concentrations of saponnins, tannins, oxalate and alkaloids. Although Kochia oxalate content was reduced by ensiling but it had negativeeffects on serum calcium levels of animal. It is recommended that ammonium chloride should be added in animal rations at the rate of $0.5-1.5$ percent to prevent oxalate toxicity (Knight and Walter, 2003 and EFSA, 
2012). Also, adding some types of clay (bentonite, tafla, kaolin and zeolite) for Kochia rations could alleviate the adverse effect of some secondary metabolites on animal's nutrition and subsequently their production (El Shaer, 2016). For that purpose, the present study aimed at improving Kochia silage utilization in sheep feeding through ensilingKochia with some feed additives (ammonium chloride or bentonite).

\section{Material and Methods:-}

The present study was conducted at South Sinai Research Station, Desert Research Center,South Sinai governorate and included three parts:

\section{The first part: Kochia plantation and silages preparation:-}

Kochia (Kochiaindica)were planted at the farm of the Research Station;the soil was characterized by loamy sand texture where EC was approximately $10 \mathrm{ds} / \mathrm{m}$ depicting it as strongly saline. The $\mathrm{CaCO} 3, \mathrm{Cl}, \mathrm{Na}, \mathrm{Ca}, \mathrm{Mg}$ and $\mathrm{K}$ concentrations were $40,42,11.6,15.2,10.8$ and $7.5 \mathrm{mg} / 100 \mathrm{mg}$, respectively.

Ground water was used for irrigation of which total dissolved salt was about $7000 \mathrm{ppm}$ using drip irrigation system. Irrigation water sample was collected regularly(monthly)to assess it chemical analyses. The $\mathrm{pH}$ was 6.1 and EC was $13.2 \mathrm{ds} / \mathrm{m}$. The soluble cations as $\mathrm{Na}^{+}, \mathrm{K}^{+}, \mathrm{Ca}^{++}, \mathrm{Mg}^{++}$were $86.3,0.42,32,34 \mathrm{meq} / \mathrm{L}$, respectively. While the soluble anions as $\mathrm{HCO}^{-}, \mathrm{Cl}^{-}, \mathrm{So}^{-}$were $2.5,112,36.7 \mathrm{meq} / \mathrm{L}$, respectively.

The plant was harvested and collected at mid bloom stage then mechanically chopped $(3-5 \mathrm{~cm})$ to facilitate handling, decrease loss of the plant and increase surface of such plant for enzymatic action and micro flora for good ensiling process.

Three tons of chopped plants were divided into three equal portions. The first portion was left without any feed additive to produce the first silage 1 (S1) but the second portion was mixed with $1 \%$ ammonium chloride on $\%$ dry matter basis to make silage 2 (S2). The third portion of chopped Kochia was mixed with $5 \%$ bentonite on $\%$ dry matter basis for silage 3 (S3).Ensiling processwas done in 3 separate pits with dimension $2.0 \times 1.0 \times 1.5 \mathrm{~m}$ length, width and height, containing one tone/pit for each. The ensiled chopped Kochia mixed with $15 \%$ molasses was filled in layers, stacked by trampling and finally covered with plastic sheets and $30 \mathrm{~cm}$ layer of sand to insure anaerobic conditions. Representative samples of silages were taken to determine the physical and fermentative traits after 45 days.

\section{The second part: Digestibility trial:-}

The experimental procedures were approved by the animal and poultry production division on Desert Research Center and as followed by the veterinary and animal care department. A digestibility trial was conducted using twelve adult rams for 45 days. Animals were divided randomly into 3 groups (4 in each) according to their body weights. The Rams were fed one of the following experimental rations:

Group1: Kochia silage(S1) as a sole ration

Group2: Kochia silage (S2) as a sole ration

Group3: Kochia silage (S3) as a sole ration

The initial live body weights were 41.141 .8 and $44.4 \pm 1.34 \mathrm{~kg}$ for $1^{\text {st }}, 2^{\text {nd }}$ and $3^{\text {rd }}$ groups, respectively.

At the beginning of the digestibility trial, the three animal groups were fed ad libitumKochia silages to determined voluntary feed intake (palatability) for 30 days. Then theywere fed individually in metabolic cages for 15 days ( 7 days as an adaptation period followed by 8 days as a collection period).Rumen liquor was collected at the end of collection period. Feed offered, feces and urine excretion were collected daily then weighed, sampled and recorded. Fresh drinking water(averaged $700 \mathrm{ppm}$ total saline) was available free choice. Representative samples from feeds, feces and rumen liquor were kept for chemical analysis.

\section{The third part: Ewes feeding trial:-}

Thirty nine pregnant Barki ewes aged 3- 4 years were selected after 4 months of gestation and randomly distributed into three groups (13 ewes in each). The initial live body weights were $37.5 \pm 0.36 ; 40.0 \pm 0.29$ and $40.08 \pm 0.260 \mathrm{~kg}$ for the $1^{\text {st }} ; 2^{\text {nd }}$ and $3^{\text {rd }}$ group, respectively. Ewes in each group were given one of the offered rations (S1, S2, and S3) during the digestibility trial as sole diets. The traditional concentrate feed mixture(CFM) was offered to all animals as feed supplement to cover $60 \%$ of energy maintenance and production requirements of ewes according to the nutritional requirements of Kearl (1982)during the last month of pregnancy and lactation period, while Kochia silages were offered ad libitum. CFM was consisted of $20 \%$ un-decorticated cotton seed cake, $16 \%$ linseed cake, $29 \%$ ground yellow corn grains, $30 \%$ wheat bran, $2 \%$ molasses, $2 \%$ limestone + premix and $1 \%$ salt.

Each ewes group was fed in an individual pen with the dietary treatments for one month before the lambing date and continued during the first month of lactation period. 
Daily feed offered and refusals were collected and weighed for each group of animals to estimate the actual feed intake. The rations were adjusted every two weeks according to the changes in ewes live body weight. Drinking fresh water was available all the day. After kidding, lambs body weights were recorded at birth then every week up to the first month after parturition. Milk yield was recorded weekly for all ewes after parturition till the end of the first milking month using hand milking. For measuring daily milk yield, lambs were separated from ewes at 8 am to $8 \mathrm{pm}$ for recording milk yield for 12 hours, and then lambs returned to ewes. In the second day, the same procedure was done, but from $8 \mathrm{pm}$ to 8 am to estimate the total milk yield per 24 hours. Representative milk samples taken from 6 animals of each group at the first month of lactation season for chemical analysis. Blood samples were collected from jugular vein $(10 \mathrm{ml})$ glass tubes containing sodium EDTA, from all experimental ewes at the end of the experimental period. Samples were centrifuged at $4000 \mathrm{rpm}$ for $15 \mathrm{~min}$. to obtain serum which stored at $-20 \mathrm{C}$ until analysis.

\section{Proximate analysis:-}

Kochia silage samples were dried at $65^{\circ} \mathrm{C}$ for 24 hrs.to a constant weight then milling in form of powder for analysis. Lactic acid and total volatile fatty acids levels in the silages were determined by steam distillation method according toWarner (1964). Ammonia N\% in silage samples was determined according toVan Soest and Robertson (1980). Total and soluble oxalate was determined by HPLC method (Savage et al.,2000). Dry matter (DM), crude protein (CP), crude fiber (CF), ether extracts (EE) and ash of feed ingredients and feces were determined according to AOAC (2007)while carbohydrates as nitrogen- free extract (NFE) was calculated by differences. Cell wall constituents of feed ingredients as neutral detergent fiber (NDF), acid detergent fiber (ADF) and acid detergent lignin (ADL) were determined according toVan Soest (1991). Total volatile fatty acids and ammonia nitrogen was determined Warner (1964). Milk samples were analyzed for total solids, fat, protein and lactose using infrared spectrophotometry (Foss 120 Milk Scan, Foss Electric, Hillerod, Denmark) according to AOAC (2007). The ash content of milk was determined after heating in muffle furnace at 550C for 16 hour and solid not fat content was calculated by differences.Kidney function was evaluated by measuring blood urea using the colorimetric methods of Fawcett and Soctt (1960). Liver function was assessed by measuring the activities of aspartate aminotransferase (AST) and alanine aminotransferase (ALT) by the method of Reitman and Frankel (1957).Blood calcium was determined by spectrophotometer (Gindler and King, 1972). Inorganic phosphorus was determined by atomic absorption spectrophotometer according to Chapman and Pratt (1961).

\section{Statistical analysis:-}

Data of the digestibility trial was subjected to one way analysis of varianceaccording to SAS (2000) :

$Y_{i j}=\mu+T_{i}+e_{i j}$

$\mathrm{Y}_{\mathrm{ij}}$ : the observation of $\mathrm{j}^{\text {th }}$ animal treated with $\mathrm{i}^{\text {th }}$ treatment

$\mu$ : overall mean

$\mathrm{T}:$ type of ration

e : experimental error

\section{Results and discussion:- \\ Silage quality:-}

The silages quality was determined in terms of physical and fermentative quality as follows:

Concerning the physical properties, it is well known that the most important physical properties of silage are the silage smell, color and texture. The results showed that Kochia silages were free from moldy and dust smells with normal odour, have a firm texture, excellent with a bright greenish yellow color and good pleasant aroma. The data on fermentative traits of the silages showed that the $\mathrm{pH}$ value of Kochia silage is used more commonly than any other chemical test and it is an important measure which reflects the changes occurred during ensiling(El Shaer, 2016). Moreover, it is a simple method to predict silage quality. Kochia silages were characterized by low $\mathrm{pH}$ (acidic) and ammonia N\%, high content of lactic acid and total volatile fatty acids (TVFA) as shown in Table 1, which indicated good quality silage. Kochia ensiled with ammonium chloride (S2) attained the highest levels of pH, TVFA'sand ammonia-Ncompared to those of the other silages, Singhet al (1996) registered the highest $\mathrm{pH}$ values and ammonia-N levels, associated with higher anaerobic proteolytic bacterial populations, in Sorghum bicolor silages (34\% DM) ensiled with $0.5 \%$ urea. Similar trend was obtained for other NPN feed additives, such as ammonium sulphate and biuret, either alone or in combination with urea (Kung and Muck,1997).

Data on proximate chemical composition and fiber constituents of Kochia silages are shown in Table 2.High level of crude protein was recorded in Kochia ensiled with ammonium chloride(S2) compared to other silages (S1 and S3), it seems that addition of ammonium chlorideraises $\mathrm{pH}$ value that inhibition protein-degrading bacteria resulting in 
silage with high protein concentration (Muck and Pitt, 1993). Either S2 or S3 attained lower levels of CF, ADL and ADF compared to S1. For instances, CF values were lower in S2 and S3 by approximately 23 and $30 \%$, respectively.; might be due to the additives treatments effect (Mir et al., 1990 and El Shaer, 2010). Meanwhile S3 contained the highest ash $\%$ as result of bentonite addition to ensiled material.Total and soluble oxalate recorded similar values for all silages which averaged $3.2 \%$ and $1.25 \%$, respectively. The same result was obtained by ElEssawyet al. (2009) who found that kochia hay or haylage had nearly similar total oxalate content (1.25 and 1.13 $\mathrm{mm} / \mathrm{g})$.

Table 1. Fermentation traits of Kochia silages

\begin{tabular}{|l|l|l|l|}
\hline Items & $\begin{array}{l}\text { Kochia silage } \\
(\mathrm{S} 1)\end{array}$ & $\begin{array}{l}\text { KochiaSilage+ammonium } \\
\text { chloride(S2) }\end{array}$ & Kochiasilage+bentonite (S3) \\
\hline $\mathrm{pH}$ value & 4.1 & 4.7 & 4.3 \\
\hline Lactic acid, \%DM & 4.8 & 4.2 & 5 \\
\hline TVFA's, meq/100 ml & 4.12 & 4.26 & 3.9 \\
\hline Ammonia N, \% DM & 0.17 & 0.22 & 0.19 \\
\hline
\end{tabular}

Table 2. Chemical composition, fiber constituents and oxalate fraction of Kochia silages, as $\%$ on DM basis

\begin{tabular}{|l|l|l|l|}
\hline Items & $\begin{array}{l}\text { Kochia } \\
\text { Silage }(\mathrm{S} 1)\end{array}$ & $\begin{array}{l}\text { Kochia silage }+ \\
\text { ammonium chloride }(\mathrm{S} 2)\end{array}$ & Kochiasilage + bentonite (S3) \\
\hline DM & 39 & 42 & 36 \\
\hline OM & 83.7 & 85.7 & 77.3 \\
\hline CP & 11 & 12.4 & 11.1 \\
\hline CF & 32.5 & 26.5 & 25.1 \\
\hline EE & 1.41 & 1.43 & 1.2 \\
\hline NFE & 38.79 & 45.37 & 39.9 \\
\hline Ash & 16.3 & 14.3 & 22.7 \\
\hline NDF & 62.9 & 61.4 & 61.5 \\
\hline ADF & 44.8 & 42.5 & 39.8 \\
\hline ADL & 16.7 & 14.8 & 15.4 \\
\hline Total oxalate & 3.4 & 3.1 & 3.2 \\
\hline Solubleoxalate & 1.23 & 1.20 & 1.27 \\
\hline
\end{tabular}

\section{Digestibility trial:-}

Data of feed intake and nutritive values of the three tested silages are shown in Table 3 . The highest dry matter intakes were recorded $(P<0.05)$ for animal in group2 fed $\mathrm{S} 2$. This is may be due to that ammonium chloride addition had a positive effect in reducing CF, ADF and ADL content of silage compared to S1(Table 2). Whereas the lowest intake was found for rams fed S3 (Kochiaensiled with bentonite) in group3 which could be attributed to higher ash content of the silage.Digestibility coefficients of all feed nutrients for Kochiaensiled with bentonite (G3) were significantly $(P<0.05)$ improved compared with the other silages (G1 and G2). The improvement of all food nutrients digestibility for animals fed S3 could be attributed to the impact of bentonite that decreased rate feed of passage through digestive tract subjecting the nutrients to enzymatic action for long time(Pashaet al., 2008). Nutritive values (TDN and DCP \%) followed the same trend of nutrients digestibility. TDN values of S3 were about $16 \%$ higher than that of S1 while DCP values of S3 were significantly higher 34 and $11 \%$ than those of S1 and S2, significantly due to higher significant digestion efficiency $(P<0.05)$ of most nutrients in S3.

Total Volatile fatty acids (TVFA's) concentration in the rumen (Table 4) depends on factors such as digestibility, rate of absorption, rumen $\mathrm{pH}$, rate of digesta passage from rumen to other parts of the digestive tract as well as the microbial population in the rumen and their activities(Flattet al., 1956). It reached maximum levels 3 hours post feeding for the three animal groups. It seems that, neither S2 nor S3 affected TVFA,s concentrations among animal groups. This results were in harmony with those of (Jacques et al. 1996) who found thatruminal TVFAs or VFA,s fraction levels of steerswere not affected when was fed sorghum silage supplemented with $1 \%$ sodium bicarbonate or $2 \%$ sodium bentonite. 
Table 3: Feed intake, digestibility coefficients and nutritive values during the digestibility trial

\begin{tabular}{|c|c|c|c|c|c|}
\hline Items & G1 & G2 & G3 & $\pm \mathrm{SE}$ & F. test \\
\hline No. of animals & 4 & 4 & 4 & & \\
\hline Live body weight, $\mathrm{Kg}$ & 41.1 & 41.8 & 44.4 & 134 & \\
\hline \multicolumn{6}{|l|}{ Dry matter intake : } \\
\hline g / head / day & $645^{\mathrm{a}}$ & $835^{\mathrm{a}}$ & $433^{b}$ & 59.8 & $* *$ \\
\hline g / Kg body weight & $15.6^{\mathrm{a}}$ & $20.1^{\mathrm{a}}$ & $9.89^{b}$ & 1.46 & $* *$ \\
\hline $\mathrm{g} / \mathrm{Kg} \mathrm{W}^{0.75}$ & $39.5^{b}$ & $50.9^{\mathrm{a}}$ & $25.4^{\mathrm{c}}$ & 364 & $* *$ \\
\hline \multicolumn{6}{|l|}{ Digestibility coefficients\% } \\
\hline $\mathrm{DM}$ & $50.6^{b}$ & $44.7^{b}$ & $65.5^{\mathrm{a}}$ & 3.11 & $* *$ \\
\hline OM & $47.1^{\mathrm{ab}}$ & $43.5^{b}$ & $54.6^{\mathrm{a}}$ & 14.5 & $*$ \\
\hline $\mathrm{CP}$ & $50.8^{b}$ & $55.4^{\mathrm{b}}$ & $68.9^{\mathrm{a}}$ & 2.64 & $* *$ \\
\hline $\mathrm{CF}$ & $54.2^{\mathrm{b}}$ & $52.2^{\mathrm{b}}$ & $65.9^{\mathrm{a}}$ & 2.34 & $* *$ \\
\hline $\mathrm{EE}$ & $48.9^{b}$ & $64.7^{\mathrm{a}}$ & $71.6^{\mathrm{a}}$ & 3.81 & $*$ \\
\hline NFE & $44.2 \mathrm{a}^{\mathrm{b}}$ & $34.4^{b}$ & $58.1^{\mathrm{a}}$ & 3.99 & $*$ \\
\hline \multicolumn{6}{|l|}{ Nutritive values , \% } \\
\hline TDN & 42.7 & 39 & 49.7 & 2.15 & ns \\
\hline DCP & $5.72^{b}$ & $6.93^{\mathrm{a}}$ & $7.66^{\mathrm{a}}$ & 0.289 & $* *$ \\
\hline
\end{tabular}

a,b,c Means having different superscripts within the same row differed significantly $(P<0.05)$, otherwise no significant differences were detected.

Table 4: Rumen fermentation parameters of rams during thedigestibility trial

\begin{tabular}{|c|l|l|l|l|l|}
\hline Items & G1 & G2 & G3 & \pm SE & F.test \\
\hline TVFA`s, meq/100ml : & & & & & \\
\hline 0 hours & 4.83 & 5.17 & 5.40 & 0.249 & $\mathrm{~ns}$ \\
\hline 3 hours & 8.69 & 9.22 & 9.08 & 0.324 & $\mathrm{~ns}$ \\
\hline 6 hours & 6.53 & 6.99 & 6.94 & 0.336 & $\mathrm{~ns}$ \\
\hline $\mathrm{NH}_{3^{-} \mathrm{N}, \mathrm{mg} / 100 \mathrm{ml}:}$ & & & & & \\
\hline 0 hours & 16.4 & 15.3 & 14.2 & 0.928 & $\mathrm{~ns}$ \\
\hline 6 hours & $30.7^{\mathrm{a}}$ & $31.2^{\mathrm{a}}$ & $27.8^{\mathrm{b}}$ & 0.617 & $*$ \\
\hline & $18.7^{\mathrm{a}}$ & $21.6^{\mathrm{a}}$ & $16.5^{\mathrm{b}}$ & 0.805 & $* *$ \\
\hline
\end{tabular}

a,b,c Means having different superscripts within the same row differed significantly(P $<0.05)$, otherwise no significant differences were detected.

Moreover, Ivan (2001)concluded that feedingon palm kernel cake by-product diets with $2 \%$ bentonite had no appreciable effect on rumen fermentation in sheep.Ammonia-N levels followed the same trend of TVFA,s and recorded the maximum levels 3 hours post feeding. Their values ranged from 27.8 in group 2 to 31.2 for the control group.It seems that S3 treatment has positive effect on nitrogen efficiencythat bentonitetended to adsorbof ammonia into clay (Martin et al., 1969).

\section{Feeding trial:-}

Average dry matter intake (from silages and concentrate) did not significantly differ due to feed additives and recorded comparable values for three animal groups (Table 5).Moreover milk yield and composition were not affected as result of ammonium chloride or bentonite inclusion. The same results were obtained byCarruthers (1985)who reported that the relatively short term feeding of bentonite did not significantly affect milk yield and composition of dairy cow. Hamilton et al. (1988)concluded that adding either Sodium bentonite or limestone to maize grain had no significant effects on milk production, milk composition or live weight changes of grazing cows.

Data on birth weight and average daily gain of lambs is presented in Table 6. All criteria related to body weight changes of lambs were not affected significantly by feeding silage types fed to the three groups. However, daily gain of lambs in group3 was exceeded by $10 \%$ than their mates in the control group(S1), might be due to their milk consumption was the highest as well as the highest concentrations of milk components. Gaberet al. (2014) noticed the improving of the daily gain and live body weight of Zaraibi kids fed rations with clay addition due tothe role of 
Table 5: Average dry matter intake, milk yield and composition of ewes during the first month oflactation period

\begin{tabular}{|l|l|l|l|l|l|}
\hline Items & G1 & G2 & G3 & \pm SE & F test \\
\hline Dry matter intake g/h/d & 698 & 760 & 695 & 47 & $\mathrm{~ns}$ \\
\hline Total milk yield, $\mathrm{ml} / \mathrm{h} / \mathrm{d}$ & 766 & 689 & 775 & 50 & $\mathrm{~ns}$ \\
\hline 4\%FCM yield, ml/h/d & 442 & 406 & 489 & 50 & $\mathrm{~ns}$ \\
\hline Milk composition ,\%: & & & & & \\
\hline Total solids & 14.17 & 13.46 & 14.52 & 0.340 & $\mathrm{~ns}$ \\
\hline Fat & 4.19 & 4.27 & 4.54 & 0.184 & $\mathrm{~ns}$ \\
\hline Protein & 3.73 & 3.23 & 3.65 & 0.168 & $\mathrm{~ns}$ \\
\hline Ash & 0.823 & 0.762 & 0.862 & 0.026 & $\mathrm{~ns}$ \\
\hline Lactose & 5.43 & 5.19 & 5.47 & 0.210 & $\mathrm{~ns}$ \\
\hline
\end{tabular}

Table 6: Body weight changes of lambs during the first month of lactation period

\begin{tabular}{|l|l|l|l|l|l|}
\hline Items & G1 & G2 & G3 & \pm SE & F test \\
\hline No. of animals & 9 & 9 & 9 & & \\
Birth weight, Kg & 3.16 & 3.58 & 3.44 & 0.109 & ns \\
BW after one month, Kg & 6.77 & 6.75 & 7.39 & 0.298 & ns \\
Average daily gain, Kg & 0.120 & 0.106 & 0.132 & 0.931 & ns \\
\hline
\end{tabular}

clayson increasing digestibility and absorption of nutrients. Thesameresultswere obtained byGihadet al. (2003)for birth and weaning weights of goat and sheep.

The results showed that blood Ca values weresignificantly higher for ewes fed S2 and S3 compared to those fed control ration (Table 7). Thisresult could be explained by the hypothesis that blood calcium decreased as the level of oxalate in the diet increased (Blaneyet al., 1982). This suggests that Ca bioavailability may decrease as result of the binding with $\mathrm{Ca}$ to form calcium oxalate, a non-soluble and non-digestible compound. This result was supported by the findings of Slanina (1974) who reported that bentonite supplemented to dairy cows at 2 or $3 \%$ of the diet improved $\mathrm{Ca}, \mathrm{Mg}$ and $\mathrm{P}$ levels in blood.The same results was obtained by Gelfertet al.(2009)who reported that using ammonium chloride at 10 or $18 \mathrm{~g} / \mathrm{kg}$ feed for cow rations had higher ionized calcium in blood than that for control ration. Otherwise blood $\mathrm{P}$ levels were not affected by different additives. The concentration of $\mathrm{P}$ and $\mathrm{Ca}$ were within the normal levels at ewe's lactation period (Plus,1988).

Serum level of AST conventionally used for diagnosing human and domestic animal hepatic damage. Whereas liver enzymes such as ALT, which is a liver specific hepatocellular enzyme, released by hepatocellular damage, which used to assess liver damage (Mahgoubet al., 2008). Either ALT or AST were slightly lower for ewes fed S2 and S3 compared to those fed control ration (S1), this results may indicate the beneficial effect of ammonium chloride or bentonite inclusion on ewe's metabolism. Blood urea concentration was significantly affected by adding bentonite for Kochia silage (S3). This may be due to higher protein digestion and lower ammonia level (Table 3 and 4 ) in group 3.None of the ewes or their kids showed abnormal health problem throughout the experimental period.

Table 7: Blood biochemical parameters of ewes fed the tested silages

\begin{tabular}{|l|l|l|l|l|l|}
\hline Items & S1 & S2 & S3 & \pm SE & F.test \\
\hline Ca, mg / dl & $11.67^{\mathrm{b}}$ & $11.87^{\mathrm{ab}}$ & $12.4^{\mathrm{a}}$ & 0.143 & $*$ \\
$\mathrm{P}, \mathrm{mg} / \mathrm{dl}$ & 5.96 & 6.18 & 6.24 & 0.073 & $\mathrm{~ns}$ \\
\hline Liver function & & & & & \\
\hline AST (IU/L) & 55.85 & 54.91 & 54.76 & 0.067 & $\mathrm{~ns}$ \\
\hline ALT (IU/L) & 12.34 & 11.65 & 11.8 & 0.078 & $\mathrm{~ns}$ \\
\hline Kidney function & & & & & \\
\hline Urea N (mmol/L) & $10.37^{\mathrm{a}}$ & $9.36^{\text {ab }}$ & $8.94^{\mathrm{b}}$ & 0.12 & $*$ \\
& & & & & \\
\hline
\end{tabular}

Ca: calcium, P: phosphorus, AST: aspartate transaminase, ALT: alanine transaminase.

a,b,c Means having different superscripts within the same row differed significantly $(\mathrm{P}<0.05)$, otherwise no significant differences were detected. 


\section{Conclusion:-}

It could be concluded that either ammonium chloride or bentonite addition to Kochia silage had desirable effect on nutrient digestion, blood calcium bioavailability, kidney and liver function and consequently on Barki ewes' performance. The impact of adding such feed additives be ensiled with Kochia or other feed materials may need to be revised and evaluated during long term feeding studies at different physiological status of animals.

\section{References:-}

4. AOAC,(2007): Association of Official Analytical Chemists, Official Methods of analysis, $19^{\text {th }}$ Edition, Washington, USA.

5. Blaney, B. J., Gartner,R. J. W. and Head, T. A.(1982): The effects of oxalate in tropical grasses on calcium, phosphorus and magnesium availability to cattle. J. Agric. Sci.,Camb. 99:533-539.

6. Carruthers, V. R. (1985): Effect of bentonite on incidence of bloat, milk production, and mineral status in dairy cows. New Zealand Journal of Agricultural Research. 28(2):221-223.

7. Chapman, H. I. and Pratt, P.F. (1961):Methods analysis for soils, plants and waters. University of California.Kerkelcy, 309.

8. EFSA, (2012): European Food Safety Authority. Opinion on the safety and efficacy of ammonium chloride for bovines, sheep, dogs and cats. EFSA Journal,10(6):2738.

9. El Shaer, H. M. (2010): Halophytes and salt-tolerant plants as potential forage for ruminants in the Near East region. Small Ruminant Research, 91(1): 3-12.

10. El Shaer, H. M. (2016): Impact of Halophytes and Salt Tolerant Forage Processing as Animal Feeds at Farm Level. Basic Guidelines. pp. 388-405. In: Hassan M. El Shaer and Victor R. Squires (Eds.). Halophytic and Salt-Tolerant Feedstuffs: Impacts on Nutrition, Physiology and Reproduction of Livestock .CRC Press, Taylor\& Francis Group.

11. El-EssawyAbeer, M., Youssef, K. M., Fahmy, A. A. and El Shaer, H. M. (2009): Excretory routes of some dietary plant secondary metabolites affecting sheep nutrition. Egypt J.Nutr.and Feeds., 12(3):441-459.

12. El-ShereefAfaf A. (2016): Kochia plant as potential forage for ruminants under desert conditions. Annual Res and Rev Biol., 10(2):1-6.

13. Fawcett, J. K. and Soctt, J. E. (1960): J. Cline. Path., 13:156.

14. Flatt,W.P., Warner, R.G. and Loosli, J.K. (1956): Absorption of VFA fromreticula-rumen of young dairy calves.J.Exp. Biol., 25:135.

15. Gabr, A. A.,Al-Mwafy,A. A. and Ahmed,M. E. (2014): Influence of Clays Addition in the Ration Containing Berseem Hay Naturally Contaminated with Aflatoxin on the Zaraibi Goats' Males Performance. Asian Journal of Animal and Veterinary Advances.,9:756-766 .

16. Gelfert, C. C.,Engel, M., Maenner, K. and Staufenbiel, K. (2009): The effect of various anionic salts on ruminal $\mathrm{pH}$ and short-chain fatty acids in non-pregnant and non-lactating cows., New Zealand Vet. J.,57:225228.

17. Gihad, E.A., Shoukry, M.M., Hanafy, M.A., Mansour, A. F. and Abd El-Rahman, H.H.(2003): Secondary compounds affect intake by range sheep and goats. Egypt. J. Nutr. and Feeds., 6:1301-1310.

18. Gindler, M. and King, J.D. (1972): Rapid colorimetric determinatation of calcium in biologicfluids with methylthymol blue. Am. J. Clinc. Path., 58:376-382.

19. Hamilton, B. A., Carmichael, A. W. and Kempton, T. J. (1988): Effect on milk production of adding bentonite and reactive limestone to maize grain supplements for grazing cows. Austr. J.Exper. Agric., 28 (1):25-28.

20. Ivan M., Neill L., Alimon R. and Jalaludinb S. (2001): Effects of bentonite on rumen fermentation and duodenal flow of dietary components in sheep fed palm kernel cake by-product. Anim Feed Sci Tech., 92:127135.

21. Jacques, K. A., Axe, D. E., Harris, T. R., Harmon, D. L., Bolsen K. K., Johnson, D. E.(1996): Effect of sodium bicarbonate and sodium bentonite on digestion, solid and liquid flow, and ruminal fermentation characteristics of forage sorghum silage-based diets fed to steers. J Anim Sci., 63(3):923-32.

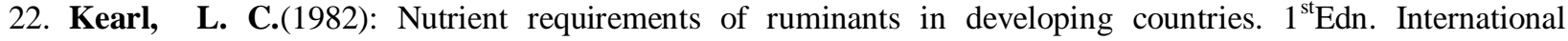
Feedstuffs Institute, Utah State Univ Logan, Utah USA.

23. Knight, A. P. and Walter R. G.(2003): Plants Causing Kidney Failure. International Veterinary Information Service (www.ivis.org), Ithaca, New York, USA.

24. Kung, L. J. R.and Muck R. E. (1997): Animal Response to silage additives. Proc. from the Silage: Fieldto Feed bunk North American Conference., 99:200-210. 
25. Mahgoub, O., Kadim, I. T., Tag Eldin, M. H., Al-Marzooq, W. S., Khalaf, S. Q., Ambuli, A.(2008): Clinical profile of sheep fed non-conventional feeds containing phenolsand condensed tannins. Small Rum. Res., 78:115-122.

26. Martin, L.C., Clifford,A.J. and Tillman,A.D. (1969): Studies on sodium bentonite in ruminant diets containing urea., J. Anim. Sci., 29:777-782.

27. Mir, Z., Bittmanz, S. and Townley, S. L.(1990): Nutritive value of kochia (Kochiascoparia) hay or silage grown in a Black soil zone in northeastern Saskatchewan for sheep. Can. J. Anim. Sci., 71:107- 114.

28. Muck,R. E. and Pitt,R. E. (1993): Ensiling and its effect on crop quality. In: Silage Production from Seed to Animal. Proceedings of the National Silage Production Conference, Syracuse, New York., 57-66.

29. Pasha, T. N., Mahmood, A,Khattab, F. M., Abdul Jabbar, M. and Khan, A. D. (2008): The effect of feed supplemented with different sodium bentonite treatments on broiler performance. Turk J Vet Anim Sci., 32(4):245-248.

30. Plus, R. (1988): Mineral levels in animal health. British Columbia, V2T 4X2, Canada.

31. Reitman, S. and Frankel, S. (1957): Amer. J. Clin. Path., 28-56.

32. SAS,(2000): SAS user' guide: Statistics SAS Inst., Inc., Cary, NC.

33. Savage, G.P., Vanhanen, L., Mason S. M., Ross, A. B. (2000): Effect of cooking on the soluble and insoluble oxalic acid content of some New Zealand foods. Journal of Food Composition and Analysis., 13:201-206.

34. Slanina, L.(1974): Buffering of the rumen contents by montmorillonite in cattle kept under industrial conditions. Deutsche TieraerztlicheWochenschrift., 81(23):552.

35. Undersander, D.J., Durgan, B. R., Kaminski, A. R., Doll, J. D., Worf, E.E. andSchulte, G. L. (1990): Alternative field crops manual: (Kochia).

36. Van Soest, P. J., Robertson, J. B. Lewis, B. A. (1991): Methods for dietary fiber, neutral detergent fiber, neutral non-starch polysaccharides in relation to animal nutrition. J Dairy sci., 74:3583-3597.

37. Van Soest, P.J. and Robertson, J.B. (1980): Systems of analysis for evaluating fibrous feeds. In: W J Pigden, C $\mathrm{C}$ Balch and M Graham (eds), Standardization of analytical methodology for feeds. IDRC 134e. International Development Research Centre, Ottawa, Canada.

38. Warner, A. C. I. (1964): Production of volatile fatty acids in the rumen: Method of measurement. NutrAbst and Rev., 34:339. 